\title{
Upper Egyptians' Use of Vehicles' Decals: Identification, Classification and Analysis of a Sample
}

\author{
Dr. Heba Abdelraheim Ibrahim Alkady
}

Lecturer in Linguistics \& Translation Studies

Qena Faculty of Arts, South Valley University

\begin{abstract}
:
Vehicles' decals reflect peoples' different attitudes socially and linguistically. New linguistic patterns can be observed over time. Language is in flux and its use accomplishes a variety of social acts. This study investigates Upper Egyptians' use of vehicles' decals in Qena. They are taken as priori to communicate. Data were collected from a sample of selected items- questionnaire -with the purpose of investigating upper Egyptians uses and attitudes towards vehicles' decals language (speech acts, aesthetic, mocking, religious, political, etc.) and the color of vehicles' decals. Decals' speech acts selections reflect the culture of users, for each individual requires a linguistic code in order to communicate his/her unique experiences. Studies with the aim of investigating peoples' discourse reflected by their vehicles' decals are rare. Therefore, this study investigates the ways Upper Egyptians use of vehicles' decals as posted on drivers' cars in Qena.
\end{abstract}

Keywords: Vehicles' Decals, Speech acts, Language Use, Upper Egypt. 


\section{استخدام أهل الهصيد لامقات المركبات تمديد وتهنيف وتهليل \\ أنمهذذج هن الالصقات \\ د هببة عبد الرحيم إبراهيم القاضي

$$
\text { كلية الآداب- جدرس اللغويات والترجمة }
$$

الالذص العربجي

تعتبر ملصقات المركبات بمثابة مرآة اجتماعية ولغوية عاكسة لآراء واتجاهات مستخدميها. فكلما مر الوقت لاحظنا ظهور أنماط لغوية واجتماعية جديدة ومتجددة. يهتم هذا البحث بدراسة آليات استخدام أهل الصعيد لملصقات المركبات في محافظة قنا تحديداً علي اعتبار أن الملصقات من وسائل التواصل والخطاب بديهياُ.تم جمع بيانات الدراسة من أنموذج تم انتقاؤه من خلال استبيان هدفت تساؤلاته إلي تحري اتجاهات أهل الصعيد وآرائهم في استخدام الأنماط المختلفة للغة شارات المركبات التي تتضمن الأفعال القولية والأقوال الساخرة وبعض ولت الأقوال الدينية والسياسية والجمالية وما إلي ذلك. بالإضافة إلي ألوان الملصقات المستخدمة حيث يعكس كل محتوي ثقافات وخبرات المتسخدمين المختلفة. وحيث أن هناك ندرة في الدراسات المهتمة بتحري خطابات واتجاهات المستخدمين التي تعكسها شارات السيارات والمركبات المختلفة, جاءت هذه الدراسة لإلقاء الضوء علي الأنماط المختلفة لملصقات المركبات المستخدمة بين مالكي وسائقي ومستخدمي المركبات في قنا تحديداً.

\section{كلمات همتتاحية:}

ملصقات المركبات, الأفعال القولية, استخدام اللغة, الصعيد. 
Identification, Classification and :Upper Egyptians' Use of Vehicles' Decals

Analysis of a Sample

Dr. Heba Abdelraheim Ibrahim Alkady

مجلة وادي النيل للاراسات والبحوث الإنسانية والاجتماعية والتربوية (مجلة علمية محكمة)

\section{Introduction}

Language is one of the most leading elements in human life; it is used to realize a variety of social and cultural targets. A sentence can be either true or false to the reality for which it stands otherwise it is "strictly speaking meaningless" (Levinson, 1994:227). A vehicle decal is considered as a discourse marker, and discourse is language in use (Brown \& Yule, 1983; Mirhosseini, 2005). A vehicle decal mostly includes speech acts.

People come across forms of vehicles' decals that include words and images of all kinds. Austin (1962:147) defines speech acts as expressions of psychological states (e.g. embarrassment, gratitude, irritation, regrets, etc.) or of involvement in social interaction (e.g. ordering, requesting, promising, warning, etc.). Austin (ibid, 108) also emphasizes that, in uttering a sentence, three kinds of acts are performed:

a. a locutionary act, which presupposes the utterance of a sentence with determinate sense and reference (i.e. the study of meaning);

b. an illocutionary act, which presupposes the making of a request, statement, promise, offer, asking a question, issuing an order, etc. in uttering a sentence, on account of the conventional force/ intention associated with it or with its explicit paraphrase;

c. a perlocutionary act, which presupposes the bringing about of effects on the addressee(s) by uttering the sentence, these effects depending on the circumstances of the utterances.

Searle sheds light on the issue of speech acts, which he defines them as "the basic or minimal units of linguistic communication" (1994:16). A Vehicle's decal is used as a 
مجلة وادي النيل للاراسات والبحوث الإنسانية والاجتماعية والتربوية (مجلة علمية محكمة)

(ISSN : 2536 - 9555)

platform for communication. Decals display some cultural or social or political messages or rude speech. Studies with the aim of investigating peoples' discourse reflected by their vehicles' decals are rare. Therefore, this study investigates the ways Upper Egyptians use of vehicles' decals as posted on drivers' vehicles' in Qena.

\section{Aim of the Study}

This paper is concerned with written decals posted on Upper Egyptians' vehicles (cars or taxis or tuk-tuks or buses). Studies on vehicles' decals mostly focused on their significance as a means of social communication. However, studies of this kind and studies investigating people's attitudes towards vehicle decals in Qena have not been academically approached. To the knowledge of the researcher, this study is the first to investigate such a sociolinguistic phenomenon in Qena. The objective of this study therefore is primarily to investigate peoples' attitudes towards vehicles' decals.

\section{Literature Review}

Actually, literature review does not show studies on language use or speech acts in vehicles' decals in Upper Egypt since; they have not been dealt with in academic research in Upper Egypt. Scholars studying graffiti or stickers on various vehicles used many different terms to refer to this phenomenon: Thematic Analysis of Vehicle Graffiti on the Roads of Egypt (M. El-Nashar, 2016), truck graffiti (Basthomi, 2009; Farnia \& Tohidian, 2013), or car written manuscripts (Divsalar \& Nemati, 2012), vehicle stickers (Chiluwa, 2008), Bumper stickers (Bloch, 2000; Case, 1992 Salamon, 2005, House, 2007).

For the purposes of this study, the study opts for the term 'vehicles' decals'. Many Upper Egyptians, out of prestige, began to stick on their cars stickers showing their careers or 
Identification, Classification and :Upper Egyptians' Use of Vehicles' Decals

Analysis of a Sample

Dr. Heba Abdelraheim Ibrahim Alkady

مجلة وادي النيل للاراسات والبحوث الإنسانية والاجتماعية والتربوية (مجلة علمية محكمة)

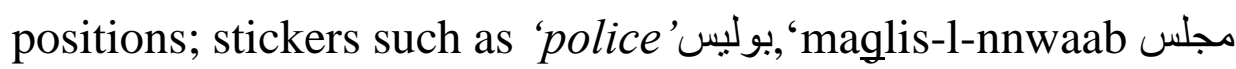
'النواب 'parliament', or something like 'vip'.

These decals were mainly in Arabic and English languages. Upper Egyptians started to stick decals that show a lover's pledge in a form of few words or a poetic verse. Most of these love decals appeared in Arabic language; mainly in Egyptian Arabic.

As a diglossic language, Arabic has three variations used by Arabic speakers. In Egypt, the three levels of Arabic: Classical Arabic, which is the language of the Quran and classical Arabic literature; Modern Standard Arabic or fuS $\mathrm{S}^{\mathrm{h}}$, which is the language used in written texts (i.e. the press and formal settings) and finally vernacular Arabic or colloquial Arabic, which is the language used for everyday conversations.

Content analyses of vehicles' decals through ethnographic methods and approaches in social psychology show that decals are discursive means of expressing emotions and social status (Newhagen and Ancell, 1995) and a spontaneous medium of protest evolving into a routinized form of public discourse after the Egyptian revolution of 2011.

Individuals generally use decals or stickers to show their support and allegiance to an organization; spread the message of interest groups, and communicate candidate preferences in social and political campaigns (Endersby and Towle, 1996; Salamon, 2001).

\section{Theoretical Framework}

Studying Vehicles' decals draws the attention of sociolinguists. It helps create a 'record of overt attitudes towards language, linguistic features and linguistic 
stereotypes' (Labov, 1984: 33). Language attitudes may vary, "people usually assign various attributes to language forms; they may feel that a language or variety of a language is 'elegant', 'expressive', 'vulgar', 'guttural' or 'musical, or that one language form is 'more polite' or more 'euphemistic or dysphemistic' than the other" (Thomas, 2004: 194).

Literature shows three approaches to studying people's attitudes towards language. These approaches are the 'content analysis' approach (Knobs and van Hout 1988:6), direct approach and indirect approach (Garret, 2010).The direct approach has been the most dominant paradigm in language attitudes' studies (see for example, Hyrkestedt \& Kalaja, 1998; Soleimani \& Hanafi, 2013; Dashti, 2016, 2014, 2008).

Literature reveals that different approaches to the study of decals were applied by academic scholars. Heider (2012:4), in the Egyptian post-revolution situation, portrays graffiti as a true replication of 'the beat of the street.'

Drivers of vehicles rolling the streets of Qena write on their vehicles various messages that differ in nature but, reflect the social, religious and political identities and beliefs and serve as a platform for social communication. The more public the decals are, the lesser the indecency of the messages. Decals sometimes express sophisticated ideological messages that reflect individual opinions on a mass scale.

Newhagen and Ancell, (1995), for example, believe that content analyses of vehicles' stickers in social psychology show that stickers are discursive means of expressing emotions and social status whereas Bloch (2000) believes that they are a spontaneous medium of protest evolving into a routinized form of public discourse. Endersby and Towle (1996) and Salamon (2001) claim that individuals use bumper stickers, in general, to display their support to an organization 
and to stretch the message of interest groups, and communicate candidate preferences in a political campaign.

Following Fairclough's (1995) post structuralist model of discourse analysis, El-Nashar (2016) investigated vehicles' graffiti in Egypt, through analyzing their patterns of usage, to see if they act as an expression of social values, religious ideologies and political affiliations.

\section{Data Collection}

The data comprises a sample of written decals taken from in-city vehicles from various parts of Qena. This paper also throws light on some of the features of decals and tackles the language and language variations used. Results show that religious expressions constituted more than half the data. The analysis reveals a strong positive disposition in the social and philosophical expressions with almost very few political decals.

Findings also reveal that some attitudes were partly influenced by the participants' ages, gender as well as levels of education and maturity. For the sake of data collection, a sample of vehicle decals is collected in Qena and, hence, analyzed.

\section{Establishing the Corpus}

The corpus consists of a sample of written decals and their possible translations. Vehicles' Decals promote various services and general interest issues. A Vehicle's decal is an 'indicator of identity...group affiliation by means of stereotypes and identity manifestation is a matter of relative choice, "relative" because group membership is a social process involving the individual member and the group" (Coulmas, 2013: 171). 
مجلة وادي النيل للاراسات والبحوث الإنسانية و الاجتماعية والتربوية (مجلة علمية محكمة)

(ISSN : 2536 - 9555)

\section{Speech Act Vehicles' Decals}

Vehicles' decals function as a dynamic means of social communication in the Egyptian society. The analysis of the corpus reveals that some types of speech acts are present in vehicles' decals making up our corpus. These speech acts are described taking into account both the point of view expressed by some scholars and our own observations:

1. assertions, which are positive claims about the world, issue, addresser, addressee or other facts, usually made without evidence, etc;

$$
\text { اضحك في أمل }
$$

Laugh, hope is still there (Cheer up).

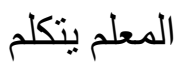

Who leads who talks

$$
\text { و اثق الخطا بمشي ملكا }
$$

He who is self-confident walks like a king

2. advice, which is an opinion expressed by the addresser with respect to how the addressee should behave or what s/he should do;

$$
\text { قول يا باسط تلاقيها هاصت }
$$

Ask the generous, He will give you , surely.

$$
\text { نضف الطاسة وخلي العربية رقاصة }
$$

Be open minded and let the car go like a dancer

$$
\text { اعمل معروف في صر مه و لا تعمله في حرمه }
$$

Do favors to anyone and anything (even shoes) and never do favor to a woman

Be patient, you all get everything

$$
\text { اصبر تنول }
$$

لو صاحبك خانك اعتبره دخانك 
Identification, Classification and :Upper Egyptians' Use of Vehicles' Decals Analysis of a Sample

Dr. Heba Abdelraheim Ibrahim Alkady

مجلة وادي النيل للاراسات والبحوث الإنسانية والاجتماعية والتربوية (مجلة علمية محكمة)

A dishonest friend is the smoke of your cigarette

3. accusations, which are charges, usually negative, against issues;

They deserve not

$$
\text { ميستاهلوشي }
$$

No friendship , no friends

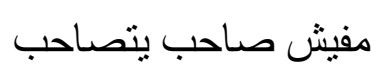

شورة المرة تجيب سنتين ورا

To consult a woman, is to blame yourself one year long

4. surprise, which is marked by the use of expressions uttered when something unexpected or unusual happens;

$$
\text { تركب اسليك, تنزل اولع فيك }
$$

Get in, be pleased. Get off, be deceased.

Regards to my bad friend

$$
\text { تحياتي لمن دمر حياتي }
$$$$
\text { حتي هدف حياتي طلع }
$$

My life goal is offside.

5. thanking, which resorts to expressions of gratitude;

Thank you dear friend.

$$
\text { شكر ا يا صاحبي }
$$

تركب الباص اثيلك فوق الر اس

Get in my bus, you are most welcome.

6. warnings, which are statements about what might happen in the future, usually with unpleasant connotations

$$
\text { متبصش كده يا عبيط دي الحلوة بالتقسيط }
$$

Don't envy me; my sweetie car is paid by instalment 


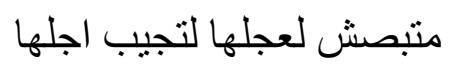

Don't look at wheels, your eyes will crackle my car.

$$
\text { متبصليش كده يا دكر دا العين فلقت الحجر }
$$

Don't envy me guy, the evil eye split stones

$$
\text { تعمل حسابي اقدرك, تهزر معايا اعورك }
$$

Give me respect, you will be appreciated (i be turned off). Show me disrespect, you will be injured (you will turn me on)

Bullying leads to prison.

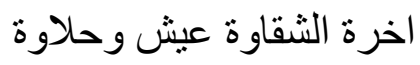

Scratch it, you will die under its wheels.

هنحكها هجييك تحتها

$$
\text { ان لقيت غر اب ابيض تلاقي صاحب يتصاحب }
$$

If you find a white crow, you will find a true friend

Take care, the driver is cockeyed.

خلي باللك السو اق احول

7. directions, which are requests for an action or information;

$$
\text { هش هش يا ديك الفرخة دي مش ليك }
$$

Go away, cock. My hen is not yours

$$
\text { اعمل معروف في صرمه و لا تعمله في حرمه }
$$

Do favors to all species (even vulgar ones) and never do favor to a woman.

8. Persuasion, which refers to the act of persuading, of convincing by emphasizing the credibility and attractiveness, by appealing to the addressee's feelings, emotions, needs, wishes, desires, to the friendly relationship established between addresser and addressee.

Your fellow Bassam is a good guy

$$
\text { اخوك بسام تباع تمام }
$$

$$
\begin{aligned}
& \text { مانثي علي رجليك لبه دا التوك توك بقي بجنيه } \\
& 108
\end{aligned}
$$


Identification, Classification and :Upper Egyptians' Use of Vehicles' Decals Analysis of a Sample

Dr. Heba Abdelraheim Ibrahim Alkady

مجلة وادي النيل للاراسات والبحوث الإنسانية والاجتماعية والتربوية (مجلة علمية محكمة)

Why are you walking on foot?! the ride costs a pound only

Invoke Allah

قول يارب

Other Vehicles' decals

a- English vehicles' decals

Allah

Love

VIP

No love no cry

Joker

\section{b- Improper English vehicles' decals}

I mes you (misspelling)

Don't look inside she is may be your mother ( ill-formed syntactic structure)

All girles under my feet (misspelling)

Please don't peep peep because I'm sleep (code-switching)

No love no frnde no maney no proplem (misspelling)

To pee or not to pee (misspelling) 
مجلة وادي النيل للاراسات والبحوث الإنسانية و الاجتماعية والتربوية (مجلة علمية محكمة)

(ISSN : 2536 - 9555)

\section{Content Based Classification}

Vehicles' decals investigated are categorized into types. They study of the investigated vehicles' decals found other categories of decals based on content analysis:

1. Religious: Deepening of faith, envy, Prayers and Thanksgivings, Preaching

$$
\text { اكفينا شر اللجان يا حنان يا منان }
$$

O Merciful Benefactor, please protect us from committees

اذكر الله

Remember Allah,

$$
\text { ربنا يحميكي من الميكانيكي }
$$

May Allah protect you "my car" from the mechanic

$$
\text { يارب احميني من العين } 2 \text { =1 و } 1
$$

one plus one equals 2 ,O Allah, protect me from evil eyes

$$
\text { قول يارب }
$$

Invoke Allah

A lion's bite is safer than an evil eye

$$
\text { عضة اسد و لا نظرة حسد }
$$

o evil people, stop envy

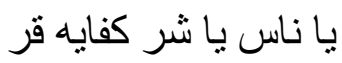

قل اعوذ برب الناس

"Say: I seek refuge with the Lord of the people"

$$
\text { قل اعوذ برب الفلق }
$$

"Say: I seek refuge with the Lord of the Dawn"

$$
\text { العين صابتني ورب العرش نجاني }
$$

The evil eye hit me, and the Lord of the Throne saved me.

2. Self- identification: Positions, memberships, careers, phone numbers, Facebook, poetry, 
Identification, Classification and :Upper Egyptians' Use of Vehicles' Decals Analysis of a Sample

Dr. Heba Abdelraheim Ibrahim Alkady

مجلة وادي النيل للاراسات والبحوث الإنسانية والاجتماعية والتربوية (مجلة علمية محكمة)

Police

Vip

مجلس النواب Parliament Council

number one نمبر ون

ابو نورا Noura's Father

الحلوة مخطوبة البرن

البرنس The prince

Princess Nouralالاميرة نور

نسر الصعيد : Upper Egypt.Eagle

3. Social campaigns : positive or negative expressions, love, wise sayings, proverbs, songs, football, tribal affiliation, nicknames, TV and cinema stereotypes, songs

Al- Ahly

Zamalik

Al - Ashraf

Hawari

$$
\text { ترجع بالسلامة يابو نور اوخلي بالك من الغندورة }
$$

Have a safe return (Abu nora) and take care of cute car

$$
\text { اخوك بسام تباع تمام }
$$

Your fellow Bassam, is a good guy

$$
\text { روتانا توكتوك مش هتقدر تمشي علي رجليك }
$$

Rotana Tuk tuk, you won't be able to close your eyes

$$
\text { متز عليش يا قطة تبقي تويوتا }
$$

Don't be angry kitty (car) tomorrow you will be Toyota

$$
\text { اللى عايز يتحير شغل له النور الصغير }
$$

He who wants to be confused, turn to him the little light on

$$
\text { الحلوة لما تتدلع. تخلي الاسفلت يولع }
$$


مجلة وادي النيل للاراسات والبحوث الإنسانية والاجتماعية والتربوية (مجلة علمية محكمة)

(ISSN : 2536 - 9555)

When sweetie moves, the asphalt turns on

Wait for me, I'll be back

استنانتي راجع تاني

$$
\text { لو كانت الثقاوة رتب كان زماني لو اء }
$$

If naughtiness is a rank, then I am a General

دي مش بالورث , دي بخلع الضرس

I didn't inherit it, I got it with hard work

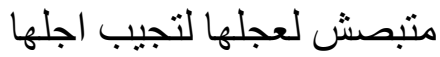

Don't look at its wheels, your eyes will crackle them.

$$
\text { إدينى تحيه و اعديك بالعربية }
$$

Greet me and I will let you go (by car)

Cuffs /kalabl/ (TV series name)

كلبش

ياتهدى يا تعدى ، دا انا محدش أدى

Drive slowly or simply pass. I am not to be competed

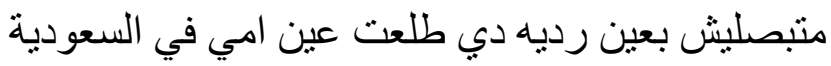

Ward off your evil eye, I suffered dog days to get it

$$
\text { احنا الاساس و الباقي شنط و اكياس }
$$

We are the core and others are plastic bags (not important)

$$
\text { ان باض الديك هعديك }
$$

I will let you pass when the cock lays eggs.

$$
\text { اللي خايف يخط احمر شفايف }
$$

If you are afraid, use lipsticks.

$$
\text { متقولش دي بكام دي جايه بدهب المدام }
$$

Don't ask how much. It costs my wife's jewelry

$$
\text { الحلوة خوخة جات بعد دوخة }
$$

Sweetie Khawkha 'lit. Peach'(name of the vehicle), is the fruit of my bending 
Identification, Classification and :Upper Egyptians' Use of Vehicles' Decals Analysis of a Sample

Dr. Heba Abdelraheim Ibrahim Alkady

مجلة وادي النيل للاراسات والبحوث الإنسانية والاجتماعية والتربوية (مجلة علمية محكمة)

$$
\text { لما كنت عصفور كلوني و لما بقيت اسد صاحبوني }
$$

When I was a sparrow like, I was wiped out, but when I became a lion, they befriended me

$$
\text { العصبة الهاشمية }
$$

Hashimi league

$$
\text { آل البيت }
$$

The family of the Prophet

$$
\text { الثريف }
$$

Sharif (descendent of the Holy Prophet)

Arab Sheikh (head or leader)

$$
\text { شيخ العرب }
$$

$$
\text { النبى عربى }
$$

The Prophet is Arab

(The Beloved or The Prophet)

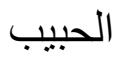

$$
\text { العرباوي }
$$

Arabain

$$
\text { الهوارى }
$$

Hawary

لتكن مشيئتك

Its Allah's will (the divine will)

Umm Elnour (Lit. Mother of Light)

$$
\text { ام النور - - ما }
$$

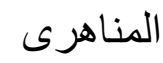

Almanahri 
Jesus

$$
\text { العذراء }
$$

The Virgin Mary

Mary

Searching for a client

$$
\text { جاري البحث عن زبون }
$$

\section{Political campaigns: patriotism, national elections}

Vote for... . انتخبو إن

Egypt is Heavenly مصر جميلة

Future of Our Native Land مستقبل وطن

Long live Egypt تحيا مصر

Yes for constitutional amendments نعم للاستور

Some of these decals are in Arabic and others in English. Recently, some decals display drivers' nickname, email, Facebook, Football, and mobile numbers.

Other decals reflect express Upper Egyptians' use of religious Qur'anic verses قل اعوذ برب الناس. قل أعوذ برب الفلقي , Muhammadالحبيب, or tribal affiliations العين صابتني ورب العرش نجاني Individuals stick the decals that appeal to them or that best express their thoughts and behaviour.

Vehicles' decals are also posted on means of transportation such as tuk-tuk ,mini buses, buses, different company mini-vans showing for example, home delivery restaurants, etc. These kinds of decals vary in size and color. Vehicles; decals in Upper Egypt are also posted on drivers' or 
Identification, Classification and :Upper Egyptians' Use of Vehicles' Decals Analysis of a Sample

Dr. Heba Abdelraheim Ibrahim Alkady

مجلة وادي النيل للاراسات والبحوث الإسانية والاجتماعية والتربوية (مجلة علمية محكمة)

owners' cars, however, these are posted on the back or back window.

\section{Discussion}

The statistical analysis shows that the questionnaire's respondents exhibited negative attitudes towards vehicles' decals in Qena, which corresponds with studies of Nashar and Nayef (2016), Mangeya (2014) and Chiluwa (2008). The data show that the respondents do not favor seeing vehicles' decals posted on vehicles. They approve of those vehicles' decals that show patriotism, but the majority also disbelieve that such decals increase solidarity. They like seeing vehicles' decals written in English, those in black and white, those in big sizes or even those which display pictures of celebrities. They believe that vehicles' decals are similar to social media devices. They don't see that they are useful in any sense .Moreover, they dislike vehicles' decals that talk about love and passion and they believe that such decals attract girls' attention. They favor seeing religious vehicles' decals.

\section{Chart 1 shows types of the decals investigated:}

\section{Chart 1}

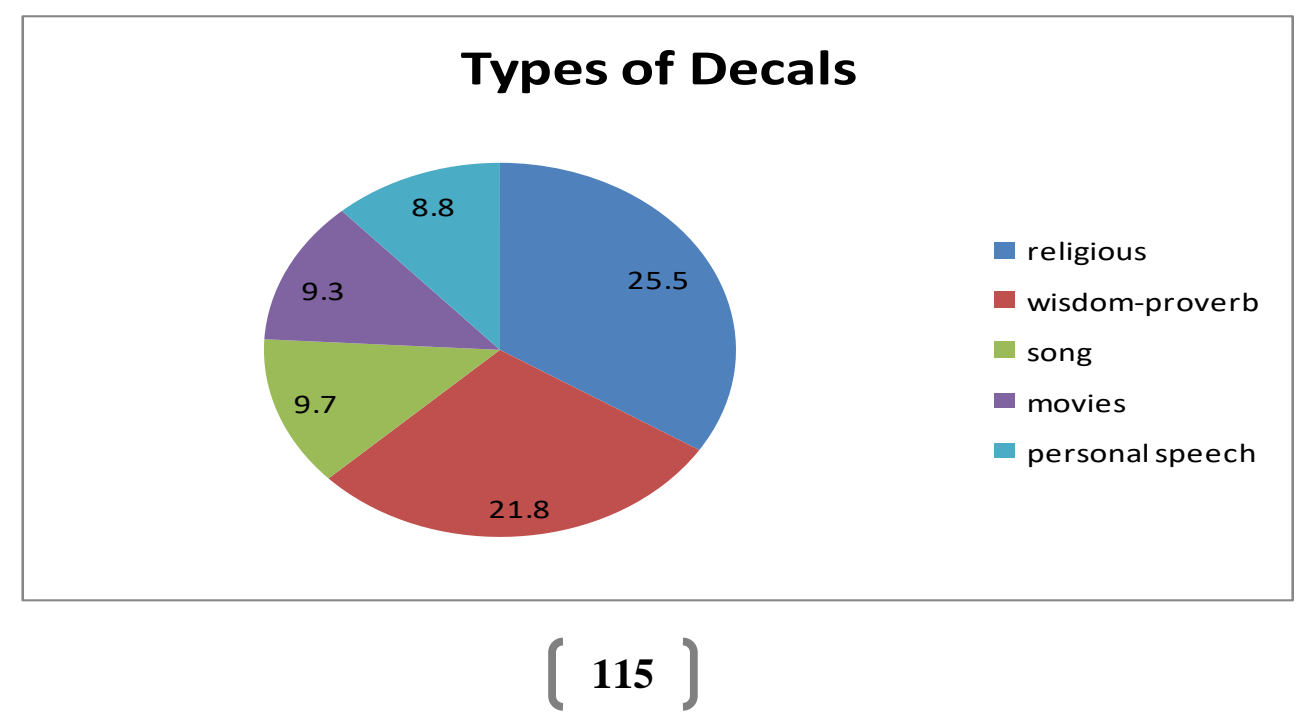


مجلة وادي النيل للاراسات والبحوث الإنسانية والاجتماعية والتربوية (مجلة علمية محكمة)

(ISSN : 2536 - 9555)

Even though language is an indicator of identity, our respondents believe that vehicles' decals as a form of language are acts of religious identity, political identity or they strengthen solidarity They believe that some vehicles' decals reflect peoples' gender and educational levels. Charts 2,3 and 4 show the average of respondents professions, gender and the types of vehicles used, respectively:

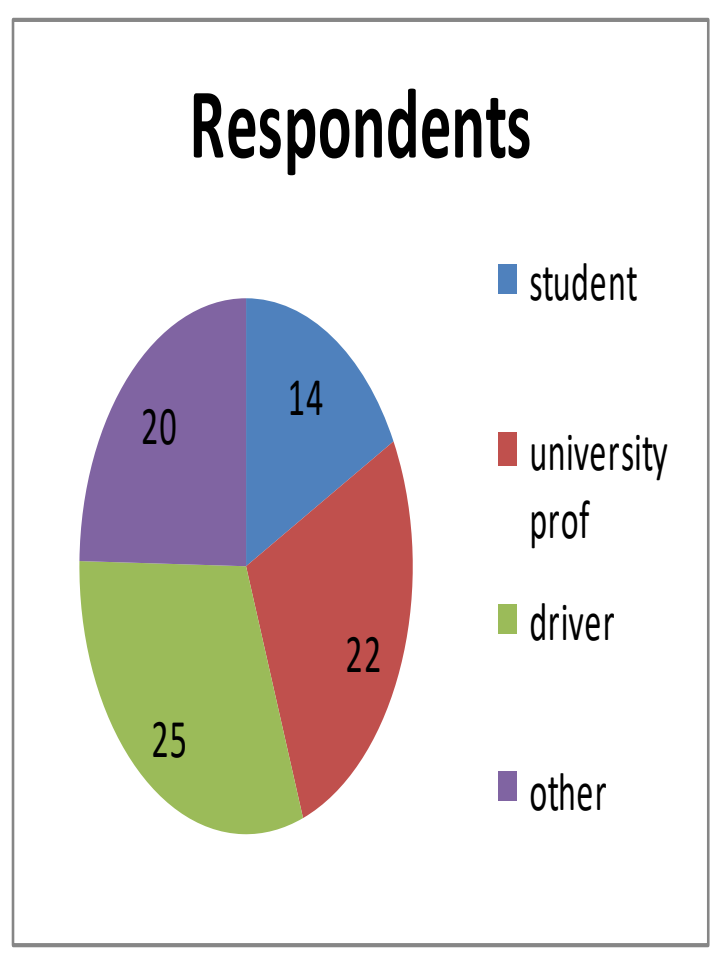

Chart 2

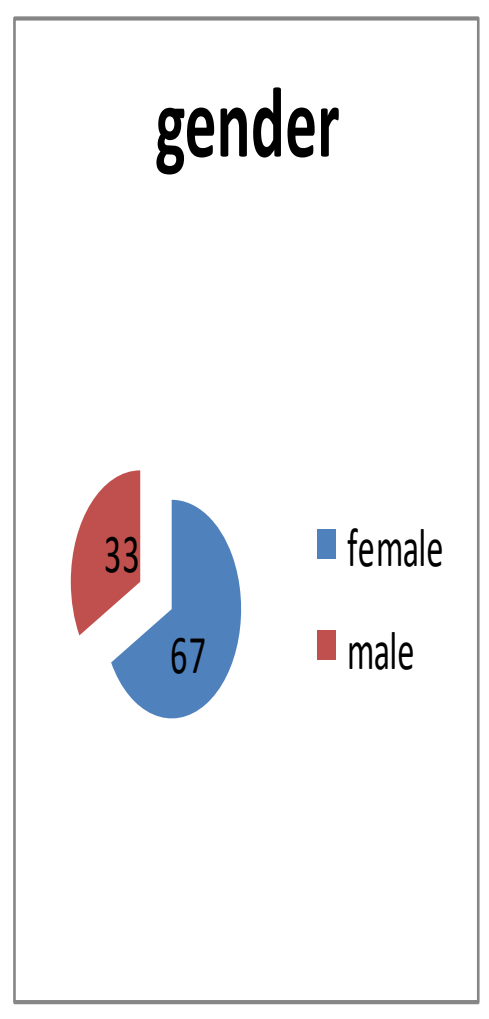

Chart 3 


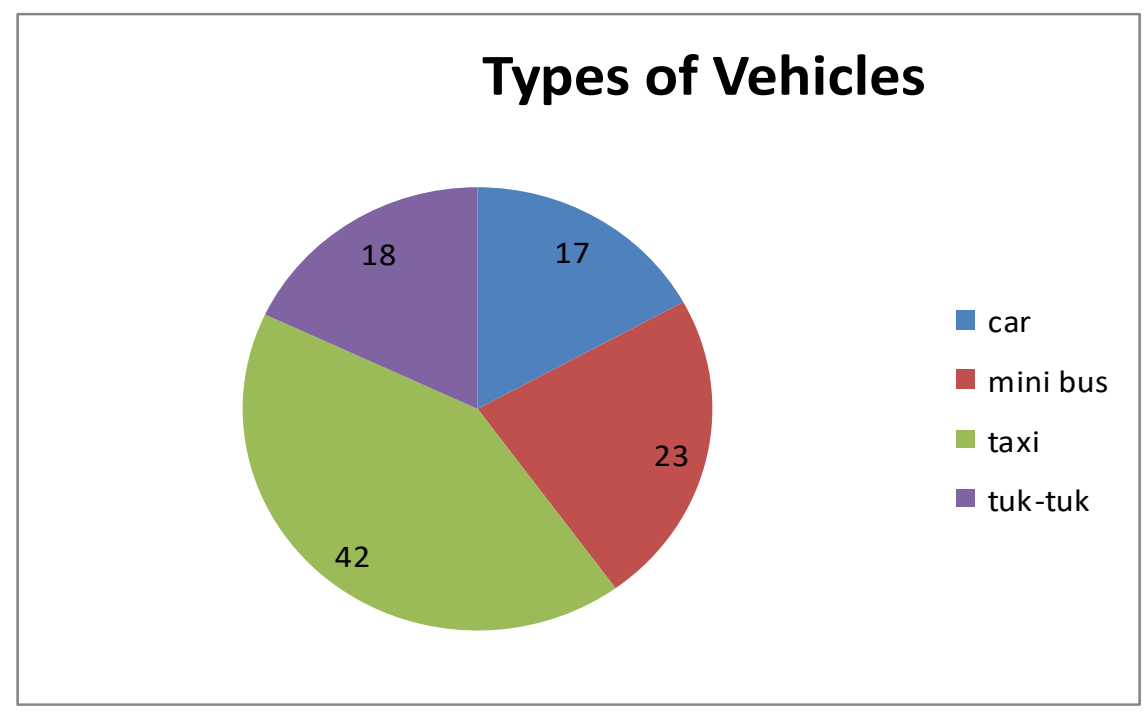

\section{Chart 4}

Religious expressions accounted for $(25.5 \%)$ decals, more than quarter the number of all respondent messages detected in the data under investigation. The remaining decal occurrences belong to the three other discourse domains.

This explains the barely existing occurrence of Christian expressions in the data, only (3\%) against (25.5\%) for Islamic expressions.

It has been found that out of (210) decals users representing all categories of discourse domain, Qur'anic decals accounted for $25.5 \%$ ) occurrences as against (21.8\%) instances of religious sayings, $(9.7 \%)$ for other proverbs, $(9.3 \%)$ for movies famous sayings, $(8.8 \%)$ for personal status, and (3\%) for Christian citations or expressions . (See Chart 5): 


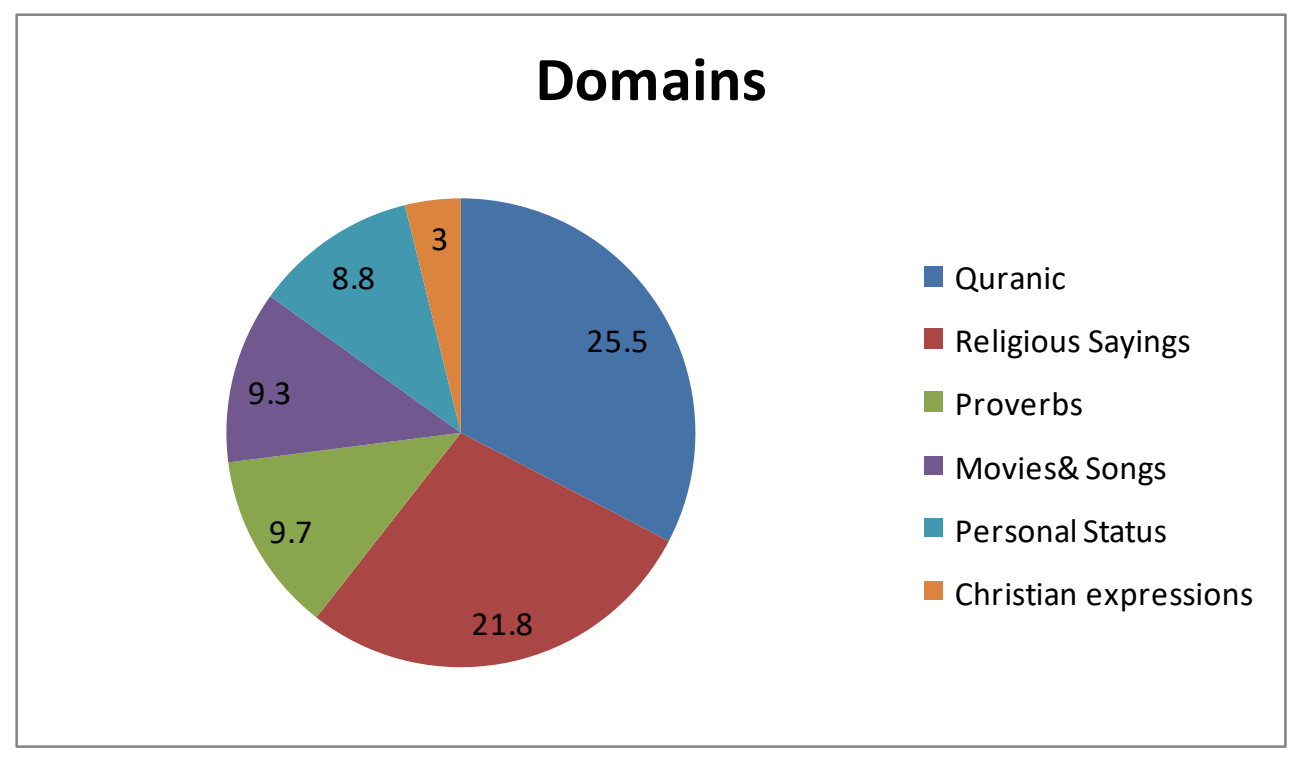

\section{Chart 5}

The majority of the religious expressions in the data under investigation fall under the category of 'reaffirmation of faith'. Three main tools were recognized: Quranic citations, religious sayings and personal declarations. Religious sayings, The 99 Names of Allah, and Names of Prophet Muhammad (pbuh), Jesus and Christian saints. Personal statuses, on the other hand, are the decals author's thoughts.

Authors used Quranic citations in the majority of cases as a tool to reaffirm faith. There were also many citations of Islamic shahadah (i.e. testimony where a Muslim bears witness that there is no god but Allah and that Muhammad is His Messenger).

It has been found that out of (210) decals users representing all categories of discourse domain, Arabic decals 
مجلة وادي النيل للاراسات والبحوث الإنسانية والاجتماعية والتريوية (مجلة علمية محكمة) accounted for $(67 \%)$ occurrences as against (32\%) instances of English ones and (1\%) for missed language. Arabic decals are classified into (67\%) occurrences for slang as against (24\%) instances of Classical Arabic, and (4\%) for upper Egyptian decals. And (5\%) English decals (See Charts 6 and 7 below):

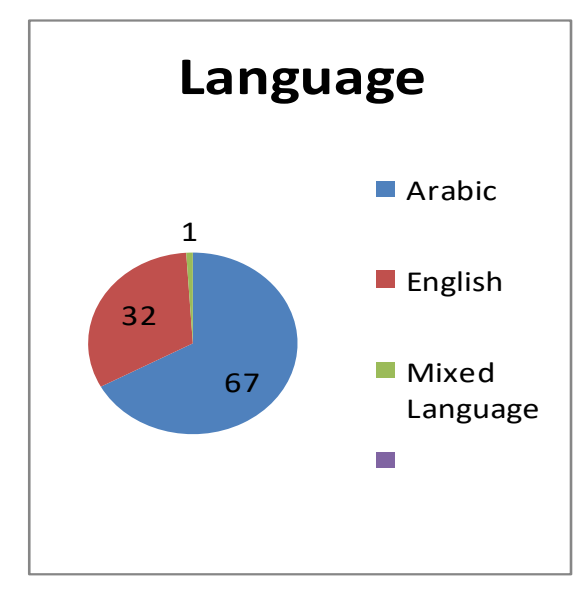

Chart 6

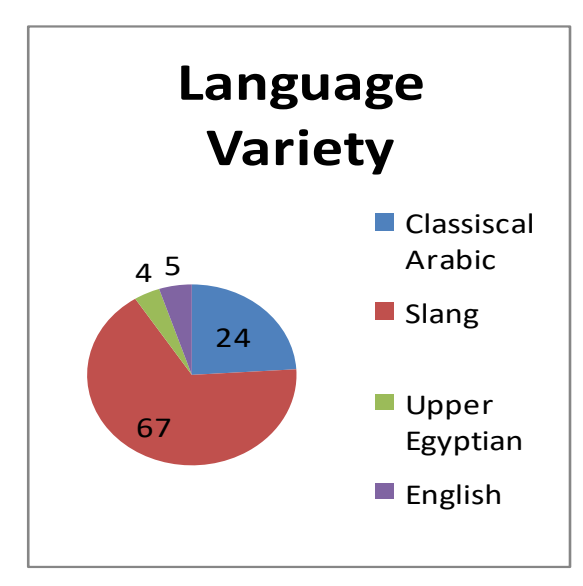

Chart 7

The majority of the expressions in the data fall under the Arabic language category. One of the dominant characteristics of Upper Egyptian society is the inherent worry of envy. Language is a pot that sediments the dominant beliefs in a society. It is found that vehicle decals not only reflect societal beliefs but also publicize them. We have found that almost a third of vehicle decals texts that fall into the religious domain (anti envy Quranic citations, common religious sayings).

It has been found that out of the (210) decals users representing all categories of discourse domain, black decals accounted for $(41 \%)$ occurrences as against (32\%) instances of white color and (21\%) for other colors. (See Chart 8): 


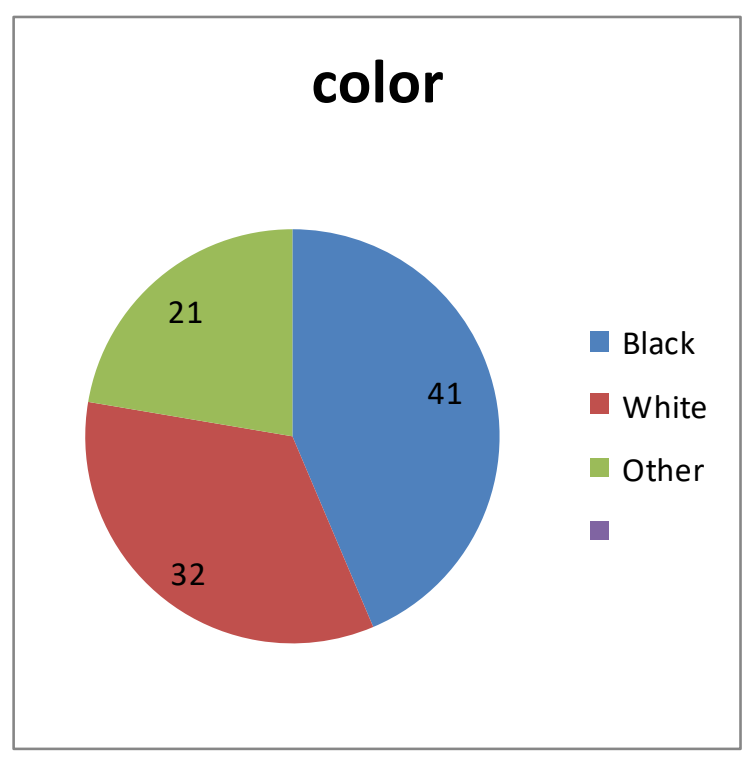

\section{Chart 8}

Some respondents believe that decals express boyish behavior; they are mostly posted by 20-25 year users ( see chart 9) when they undergo certain psychological or personal burdens or affected by a famous TV series like PilmazariiTa nisrilSaGiid, Pilzookar الجوكر and wild Pilgalaaba , ولد الغلابة العرئ

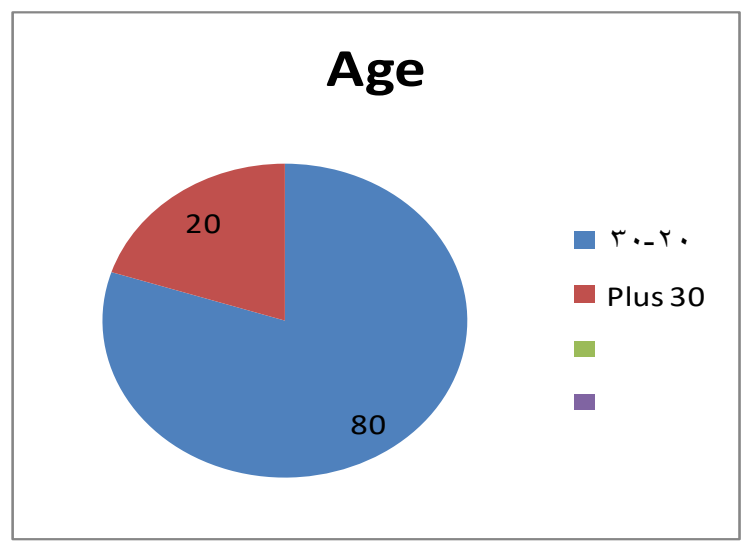

\section{Chart 9}


Identification, Classification and :Upper Egyptians' Use of Vehicles' Decals Analysis of a Sample

Dr. Heba Abdelraheim Ibrahim Alkady

مجلة وادي النيل للاراسات والبحوث الإنسانية والاجتماعية والتربوية (مجلة علمية محكمة)

Some maintained the idea that a vehicle is a means of transportation, not a means for social communication; they should be forbidden by the police. It is worth mentioning that young drivers of cars, mini vans or tuk-tuks post decals during parliament election' campaigns which display photos of some candidates or their electoral numbers. They wish if the candidate wins, they would, then, get some personal gains through his/her power.

Many respondents said that the question is what do these decals say about the person's thought or the way this person thinks. They believe that posting decals is a reflection and sometime deception. If people have positive attitudes towards their country, their religion, or even towards politics or any social phenomena, these feelings should not be posted on vehicles.

The respondents believed that those who post religious decals are females or old/mature owners of private cars; those who post decals showing usernames or nicknames or famous TV shows or football teams are immature or mostly not highly educated.

Most respondents claimed that vehicles' decals are proper and beneficial if they post decals that say 'urgent' messages, like' death vans or, those that post their mobile numbers in case one wants to complain about the driver's driving behavior, those that encourage optimism like ' Pibtasim ابتسم Smile please', or those on vans as a kind of advertisement. Some favored the decals on companies' vehicles which advertise their products, such as furniture, groceries, dessert and so on.

Proverbs or comic quotes are typical sayings which tell advice about how to act and live. Most Arabic proverbs have 
their origins in Upper Egyptian tradition; they involve encoding and intended messages which serve as a source of people's wisdom.

It is noticeable however that although few people use this kind of linguistic utterances, we cannot ignore their role in delivering and implying messages to influence people and help preserve their native or mother vocabulary.

Actually, proverbs tell the values and beliefs of a community. These values and beliefs are deemed necessary in life because they have an indispensible correlation to our essentials as they form our thought and behavior.

The majority approve posting religious decals, a few believed that the short and brief decals which may remind of the existence of Allah.

Others believed that people are free to post decals if the wording or the images don't violate others' feelings. Some favored only small decals with few words and those posted in English.

As far as gender is concerned, the statistical analysis has shown that females are interested in religious decals. As far as age and the education variables, the statistical analysis indicated that the higher the age or the level of education of the participants, the more they disapprove vehicles' decals. This seems to be self-explanatory since older age people and more educated people are more mature and self-confident, while younger people always feel that they are the kings of their domains and, hence opt to show their feelings and attitudes through any means of communication.

\section{Comments on Discussion}
1) Upper Egyptians in general, favor having vehicles' decals 
Identification, Classification and :Upper Egyptians' Use of Vehicles' Decals Analysis of a Sample

Dr. Heba Abdelraheim Ibrahim Alkady

مجلة وادي النيل للاراسات والبحوث الإنسانية والاجتماعية والتربوية (مجلة علمية محكمة)

2) Upper Egyptians favor vehicles' decals that show xenophobia

3) Upper Egyptians prefer white and black decals. They use Arabic and English as well.

4) Non adult Upper Egyptian users consider vehicles' decals as one of the social media devices.

5) Non adult and male Upper Egyptian users favor vehicles' decals that talk about TV Stereotypes. They believe that such decals attract attention.

6) Upper Egyptians favor seeing religious vehicles decals. They believe that such decals are acts of religious identity.

7) Upper Egyptians believe that some vehicles' decals reflect peoples' political identity or political bias.

8) Upper Egyptians believe that some vehicles' decals reflect peoples' educational levels.

A questionnaire was designed and distributed to 200 Upper Egyptians from different genders, ages, and educational background. .....came back and made the corpus of the study.

\section{Conclusion}

This paper investigates Upper Egyptians' attitudes towards vehicles' decals in Qena. A questionnaire is used and quantitively examined. The data are categorized and observed across sociolinguistic parameters, generally, gender, age, and level of education. The results showed that Upper Egyptians, in general, expressed negative attitudes towards vehicles' decals as displayed on vehicles, and some statistical differences as far as gender, age, and level of education were also unrevealed. 
مجلة وادي النيل للاراسات والبحوث الإنسانية والاجتماعية والتربوية (مجلة علمية محكمة)

(ISSN : 2536 - 9555)

\section{References}

Adams, K. L.,\&Winter, A. (1997). Gang graffiti as a discourse genre. Journal of sociolinguistics, 1(3), 337360.

Alonso, A. (1998). Urban graffiti on the city landscape. Western Geography Graduate Conference, San Diego niversity, February.

Bach, K. \& Harnish, R.M. (1979). Communication and Speech Acts. Cambridge, Mass.: Harvard University Press.

Basthomi, Y. (2009). Truck graffiti: The rhetoric of emulation. Dialogue Analysis XI, 217.

Bloch, L. R. (2000). Mobile discourse: Political bumper stickers as a communication event in Israel. Journal of Communication, $50(2)$ 48-76. https://doi.org/10.1111/j.1460-2466.2000.tb02841.x

Brown, G., \& Yule, G. (1983). Discourse Analysis. Cambridge: Cambridge University Press. https://doi.org/10.1017/CBO9780511805226

Bunting, A. M. (2012). A sociological study of graffiti in Seville, Spain. Journal of Student Research, 1(2), 51-54

Case, C. E. (1992). Bumper stickers and car signs ideology and identity. The Journal of Popular Culture, 26(3), 107-119. https://doi.org/10.1111/j.0022-3840. 1992. 2603_107.x 
Identification, Classification and :Upper Egyptians' Use of Vehicles' Decals Analysis of a Sample

Dr. Heba Abdelraheim Ibrahim Alkady

مجلة وادي النيل للاراسات والبحوث الإنسانية والاجتماعية والتربوية (مجلة علمية محكمة)

Chalon, Y. (1985). The Structure of Communicative Interaction. In P. Riley (Ed.), Discourse and Learning (pp. 12-19). Harlow: Longman.

Chiluwa, I. (2008). Religious vehicle stickers in Nigeria: a discourse of identity, faith and social vision.Discourse \& Communication, 2(4), 371-387. https://doi.org/10.1177/1750481308091909

Cook, G. (1996). The Discourse of Advertising. London \& New York: Routledge.

Coulmas, F. (2013). Sociolinguistics: The Study of Speakers' choices. Cambridge University Press. https://doi.org/10.1017/CBO9781139794732

Coulthard, M., \& Montgomery, M. (1981). Studies in Discourse Analysis. London: Routledge and Kegan Paul.

Danesi, M. (2016). Language, Society, and New Media: Sociolinguistics Today. Routledge, Taylor \& Francis

Group, New York \& London.

Dashti, A, (2008). The Use of Computers by Staff Members by ELT Teachers. Journal of the International Society for Teachers Education, 12(2).

Dashti, A. (2014). Investigating English Major Students' Attitudes Towards the Efficiency of the Conversation

Course. International Journal of English Language Teaching, 2(4), 56-66. 
مجلة وادي النيل للاراسات والبحوث الإنسانية والاجتماعية والتربوية (مجلة علمية محكمة)

(ISSN : 2536 - 9555)

Dashti, A. (2016). Attitudes of Kuwaiti students towards

English/Kuwaiti Arabic code switching in Kuwaiti Media. Arab Journal for the Humanities (AJH). Academic Publication Council, Kuwait University, Volume, 136, Autumn, 2016.

Divsalar, F., \& Nemati, A. (2012). Social pathology of trust in car written manuscripts. Mediterranean Journal of Social Sciences, 3(3), 363-462.

El-Nashar, M., \& Nayef, H. (2016). Discourse on the Go: Thematic Analysis of Vehicle Graffiti on the Roads of Egypt. Advances in Language and Literary Studies, 7(5). Australian International Center, Australia.

Endersby, J., \& Towle, M. (1996). Tailgate Partisanship: Political and Social Expression through Bumper Stickers. The Social Science Journals, 33(3), 307-319. https://doi.org/10.1016/S0362-3319(96)90026-9

Fairclough, N. (1995). Media Discourse. London: Arnold.

Farnia, M., \& Tohidian, I. (2013). A thematic analysis of truck graffiti in Iranian context. Paper presented at the first national conference on research in teaching English, translation and linguistics (RTELT), 2-3 March, Islamic Azad university of Khorasgan, Iran.

Gadsby, J. M. (1995). Looking at the writing on the wall: A critical review and taxonomy of graffiti texts (Unpublished MA thesis). Boston: USA.

Garret, P. (2010). Attitudes to Language. Cambridge: Cambridge University Press. https://doi.org/ 10.1017/ $\underline{\text { CBO9780511844713 }}$ 
Identification, Classification and :Upper Egyptians' Use of Vehicles' Decals Analysis of a Sample

Dr. Heba Abdelraheim Ibrahim Alkady

مجلة وادي النيل للاراسات والبحوث الإنسانية والاجتماعية والتربوية (مجلة علمية محكمة)

Grider, S. A. (1975). Con safos: Mexican-Americans, names and graffiti. The Journal of American Folklore, 88(348), 132-142. https://doi.org/10.2307/539192

Harris, Z.S. (1952). "Discourse analysis". In Language, 28: 1-30.

Heider, A. (2012). Graffiti in post-revolutionary Egypt: Using graffiti as a language source in the AFL classroom. Seminar paper: CMC \& Teacher Ed SIGs Joint Annual Seminar-Università di Bologna, 29-30 March

Hyrkestedt, I., \& Kalaja, P. (1998). Attitudes towards English and its functions in Finland: a discourse analytic study. World Englishes, 17, 345-57. https://doi.org/10.1111/1467-971X.00108

Knobs, U., \& van Hout, R., (1988). Language attitudes in the Duch language area: an introduction. In R. van

Hout, \& U. knops (Eds.), Language attitudes in the Duch language area (pp1-23). Dordrecht: Foris.

Labov, W. (1984). Field methods of the project on linguistic change and variation. In J. Baugh, \& J. Sherzer (Eds.), Language in use (pp. 28-53). Englewood Cliffs, NJ: Prentice Hall.

Mangeya, H. (2014). A Sociolinguistic Analysis of Graffiti written in Shona and English Found in Selected Urban Areas of Zimbabwe (Unpublished PhD dissertation). University of South Africa, November, 2014. 
مجلة وادي النيل للار اسات و البحوث الإنسانية والاجتماعية والتربوية (مجلة علمية محكمة)

(ISSN : 2536 - 9555)

Mirhosseini, S. A. (2005). Discourse and Power in a Multilingual World. Adrian Blackledge, John Benjamins, Amsterdam.

Mirzaalikhani, S. (2011). Iranian graffiti during political transformation: A semiotic analysis of graffiti before and after revolution (Ph.D. dissertation, Eastern Mediterranean University (EMU)). 